専門医症例報告

上顎両側遊離端欠損に対して上顎洞底挙上術後にインプラント治療を行った 1 症例

冨山 雅史

\title{
A Case of Implant Restoration with Maxillary Sinus Floor Elevation for Maxillar Bilateral Free-end Missing
}

Masashi Tomiyama

抄 録

症例の概要：患者は 48 歳の女性，上下顎曰歯部欠損による咀嚼障害を主訴に来院した。違和感により可 徹性局部床義歯はほとんど使用していなかった。上顎左右臼歯部には上顎洞底挙上術を行い，上顎左右臼 歯部と下顎右側且歯部にインプラントの固定性上部構造を装着した。

考察：定期的なメインテナンスを行っているが，インプラントの動摇や骨吸収は見受けられない.患者が 満足する機能的回復と審美的完全が行われたと思われる。また，インプラントにより咬合支持が確保され たことにより，上下残存歯の保護に役立つていると思われる。

結論：上顎両側遊離端欠損の補綴治療において，インプラント治療により患者の高い満足度が得られた。

和文キーワード

両側遊離端欠損，上顎洞底挙上術，インプラント，咬合支持

\section{ABSTRACT}

Patient: A 48-year-old female complained of masticatory disturbance caused by maxillary and mandibular distal extension missing. The patient complained of discomfort of maxillary removable denture. After maxillary sinus floor elevation, the treatment provided occlusal reconstruction with implant-supported fixed prostheses for maxilla and mandible.

Discussion: The implant prosthesis resulted in a good outcome with no mobility and no morbid bone resorption around implants during periodical recall. The patient was very satisfied with function and esthetics by the implant treatment. Establishment of occlusal support by implants also presented stabilizing of existing teeth.

Conclusion: The implant treatment effectively improved the patient's requirements for comfort in maxillar bilateral free-end missing.

\section{Key words}

bilateral free-end missing, maxillary sinus floor elevation, implant, occlusal support

東京支部（台東歯科クリニック）

Tokyo Branch (Taitou Dental Clinic)

受付 : 2010 年 3 月 9 日/受理 : 2010 年 7 月 12 日

Received on March 9, 2010/Accepted on July 12, 2010 


\section{I. 緒言}

近年，欠損補経症例に対する治療法として，インプラ ント治療が急速に普及してきている．特に，遊離端欠損 症例では，可撤性義歯に比べて違和感が少なく，十分な 咬合力を発揮できる有効な治療法であり，高い患者満足 度と QOL の向上が期待できる.

また，インプラント治療の適応として，治療部位の歯 槽骨骨量が十分にあることが前提となるが，骨量が不足 している症例も臨床では多々見受けられる。

そこで，歯槽骨骨量が不足している部位にインプラン ト治療を行う場合は，インプラント治療前の骨移植が必 要となる。

今回，骨量の不十分な上顎臼歯部遊離端欠損症例に対 して上顎洞底挙上術の後，インプラント治療を行い良好 な結果を得た症例について報告する。

\section{II. 症例の概要}

患者: 48 歳, 女性.

初診: 平成 16 年 9 月.

主訴： 6 5(4), よる咀嚼障害と前歯部の審美障害.

既往歴：特記事項なし。

現病歴：他院にて 567 局部床義歯を作製したが, 違和感と発音障害のため全く使用していない，その後， 右側の上下顎ブリッジが動摇してきたので，インプラン 卜治療を希望して当院に来院した。

現症：初診時，欠損部は， $76 \mid 567, \overline{76 \mid 67}$ で, 6 (5)4, 6(5), (5)678)の 3 カ所にブリッジが装着 されていた，6(5)(4)ブリッジは著しく動摇し，54|は

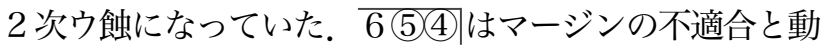
摇を認め，右側咀嚼時の疼痛を認めた，他の残存歯は中 等度歯周病に罹患しており, 歯周治療の必要性を認めた。

また，前歯部は開咬しており， 3 硬質レジン前装冠と (3)2) 1 (1)2)硬質レジン前装ブリッジの前装部は変色し, 審美障害を認めた。

$\mathrm{X}$ 検査所見：パノラマ $\mathrm{X}$ 線写真では，上顎洞底線は 明瞭で，左右臼歯部の歯槽骨頂と上顎洞底が接近してい た. 歯槽骨頂と洞底間距離は，6歯槽部で $6 \mathrm{~mm}, 6$ 歯槽部で $4 \mathrm{~mm}$ であった。粘膜の肥厚，不透過像は認 められなかった（図 1)。また，2」の根尖に透過像を認 めた。

治療方針：6 (5)(4)|支台歯である5 4|は，ウ蝕およ び歯周病のため保存不可能と診断し抜歯する。

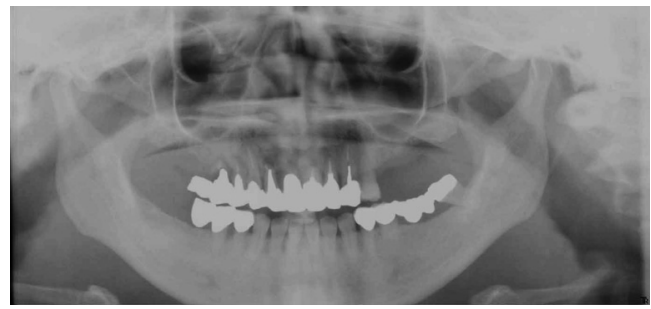

図 1 Panoramic radiograph at the first examination 初診時のパノラマ写真

は，ブリッジ不適合のため，ブリッジ除去後， 54 |の 歯冠修復の再製作を行う.

残存歯の歯周治療を並行して行い，歯周治療終了後に 欠損部分 $7654 \mid 567 ， \overline{76}$ 亿のインプラント治療 を行うことした。

また， $7654 \mid 567$ 部の歯槽骨頂と上顎洞底との 距離が少ないため，上顎洞底挙上術が必要と判断し，患 者の同意のうえ，抜歯窩治癒後，大学病院にて腸骨移植 による左右上顎洞底挙上術を行うこととした。手術半年 後に, 76 部と $7654 \mid 567$ 部にインプラントの埋 入手術を行う。

さらに，埋入手術約半年後に 2 次手術を行い，イン プラント上部構造物を作製する.

上部構造物装着後には，前歯部の審美回復と咬合状態 の改善のために，(3)(2) 1|1(2)ブリッジを除去し，陶材 焼付ブリッジを作製し，３硬質レジン前装冠を除去し， 陶材焼付冠を作製する。 また，2|の根尖病巣については， 自覚症状が無いことと，根の湾曲および既存のメタルコ アの除去が難しいことから，患者と相談の結果，経過観 察することとなった。

\section{III．治療内容と経過}

\section{1. 治療内容}

平成 16 年 9 月： 6 (5)(4)|ブリッジを除去し， 54 |を 抜歯した。また, 同時に全顎の歯周初期治療を開始した。

次に， 6 (5)(4)ブリッジを除去し， 54 |に暫間被覆冠 を作成した。

平成 16 年 11 月：歯周初期治療終了後， 54 |に陶材 燒付冠を装着した（図 2).

平成 16 年 12 月: 東京歯科大学市川病院にて, $7654 \mid 567$ 部に腸骨移植による上顎洞底挙上術を 行った.

平成 17 年 5 月 : パノラマ $\mathrm{X}$ 線撮影および $\mathrm{CT}$ 撮影 を行い, 移植部分の十分な骨量を確認した（図 3, 図 4). さらに CT 画像を参考にして，インプラントの埋入部位 


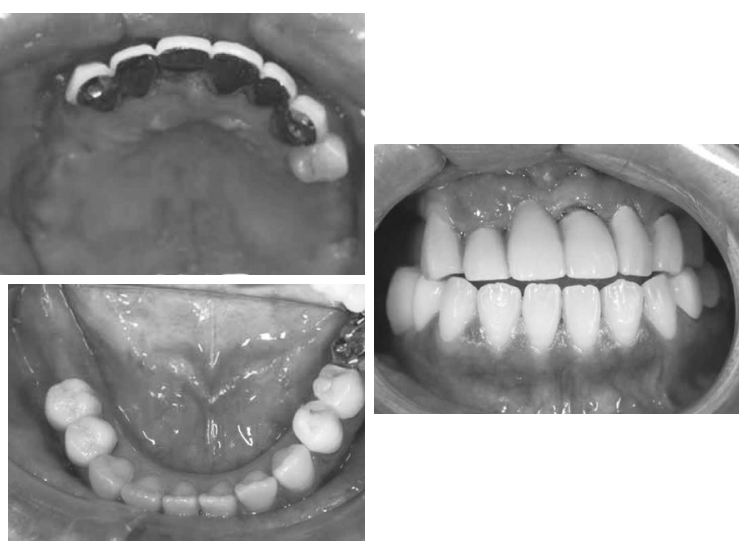

図 2 Intraoral views before sinus floor elevation 骨移植前の口腔内写真

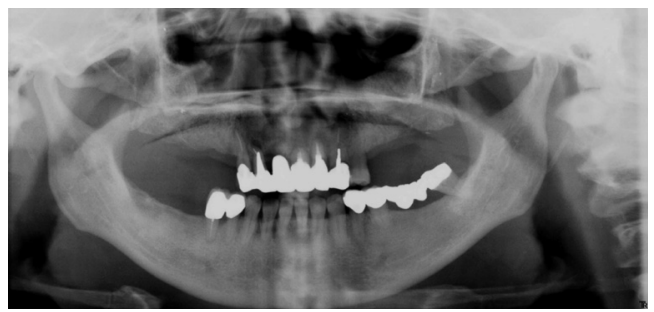

図 3 Panoramic radiograph at 3 months after sinus floor elevation

骨移植 3 力月後のパノラマ写真

および種類をシミュレーションした。

インプラント 1 次手術では, Brånemark System を 用い, 以下のように上顎に 7 本, 下顎に 3 本を埋入した。

76 部 : MK III Tiunite RP $3.75 \times 8.5 \mathrm{~mm}, 3.75$ $\times 11.5 \mathrm{~mm}, 3.75 \times 11.5 \mathrm{~mm}$.

7654 部 : MK IV Tiunite RP $4 \times 15 \mathrm{~mm}, 4 \times 5$ $\mathrm{mm}, 4 \times 15 \mathrm{~mm}$, MK III Tiunite RP $3.75 \times 13 \mathrm{~mm}$.

567 部 : MK III Tiunite RP $3.75 \times 15 \mathrm{~mm}, 3.75$ $\times 13 \mathrm{~mm}$, MK IV Tiunite RP $4 \times 15 \mathrm{~mm}$.

平成 17 年 6 月 : 患者の希望により, 3 硬質レジン前 装冠を除去し，根管治療後に陶材焼付冠を作製した。

平成 17 年 11 月: 6 力月の治癒期間後, インプラン 卜 2 次手術を行った. 浸麻下で粘膜貫通後, ヒーリン グアバットメントを装着した。粘膜の治癒後に，インプ ラント上部構造物作製のための印象採得を行った。咬合 採得後，作業用模型上で，ハイブリッド型コンポジット レジン前装冠による上部構造物を作製した（図 5).

平成 17 年 12 月: 767654 に上部構造物をス クリュー保持にて装着した。

平成 18 年 1 月 : 567 に上部構造物をスクリュー保 持にて装着した。
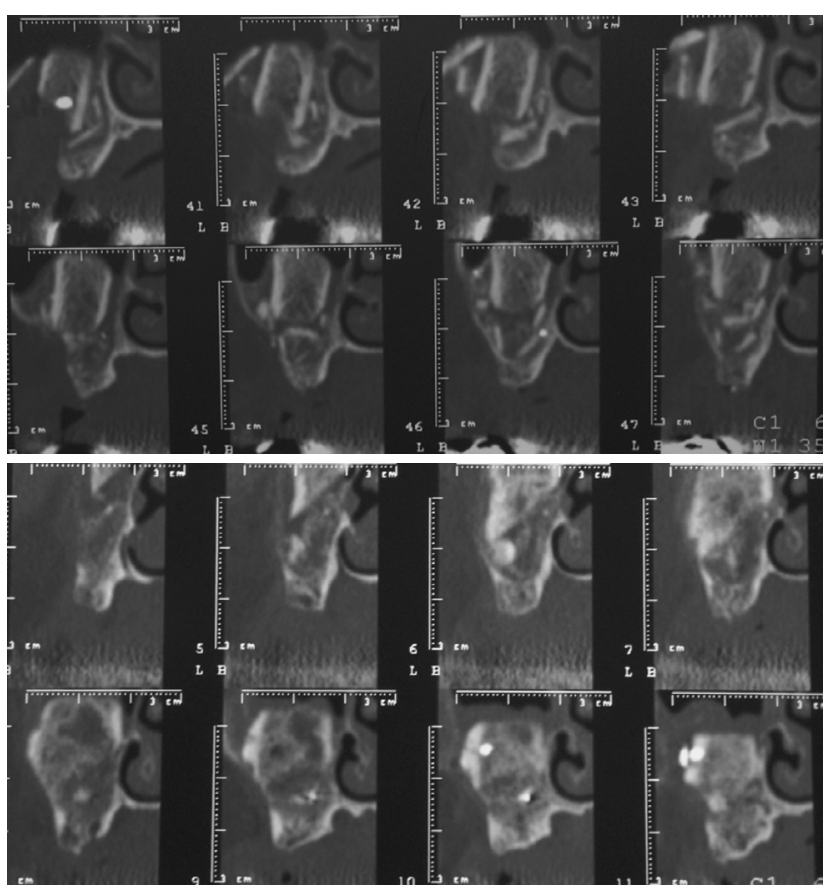

図 4 Computed tomography radiographs at 3 months after sinus floor elevation 骨移植 3 力月後の CT 画像

平成 18 年 3 月：(3) (2) 1 (1)(2)ブリッジを除去し，暫間 被覆冠を作製した。

平成 18 年 4 月：(3) (2) 1)(2)を印象採得し，陶材焼付 ブリッジを作製，装着した（図6)。

\section{2. 経過}

治療終了後, 6 カ月ごとのメインテナンスに移行し現 在に至っている.リコール時には, インプラントおよび 上部構造のみならず，口腔内全体の咬合状態，プラーク コントロールのチェックを行い, さらに 1 年に 1 度 X 線写真によってインプラント周囲骨の変化を観察してい る，現在まで特記すべき変化はなく，良好に経過してい る(図 7 , 図 8 )。

また, 平成 21 年 3 月に 2 の歯根端切除手術を行った が，前歯部ブリッジも良好に経過している.

\section{IV. 考 察}

義歯に順応できない方への欠損補綴治療としてインプ ラントは最良の治療法と言えるが，本症例のように，当 該部の歯槽骨骨量が不足している場合は，術前の骨移植 が必要になるために, 治療期間は長期にわたり, 患者の 負担も大きい. また，上顎洞底挙上術後のインプラント の存続率は技術レベルの差が反映されやすい方法であ 


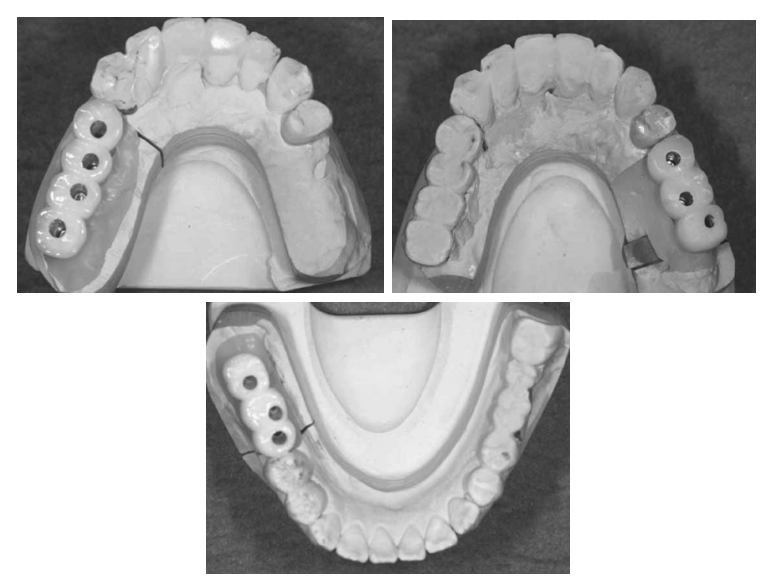

図 5 Complete of making superstructure 完成した上部構造物
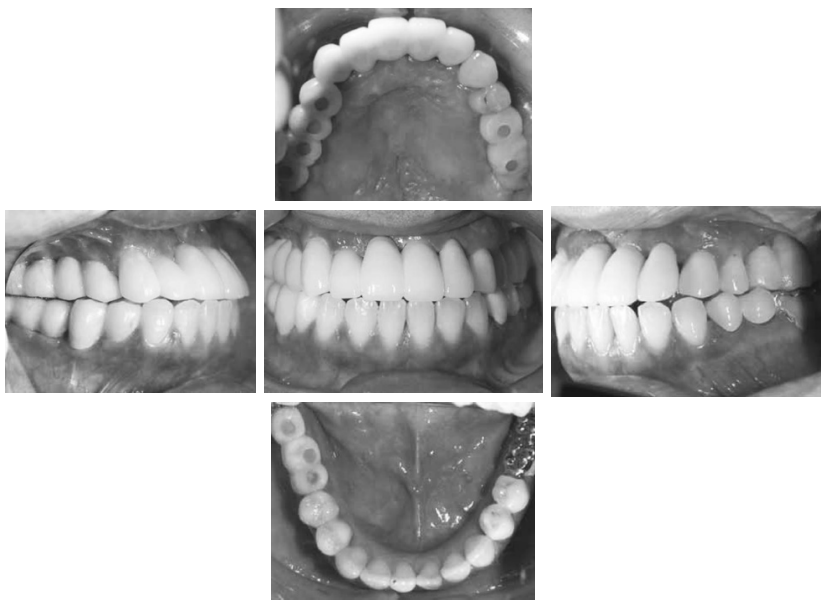

図 6 Intraoral views after treatment 治療終了時の口腔内写真

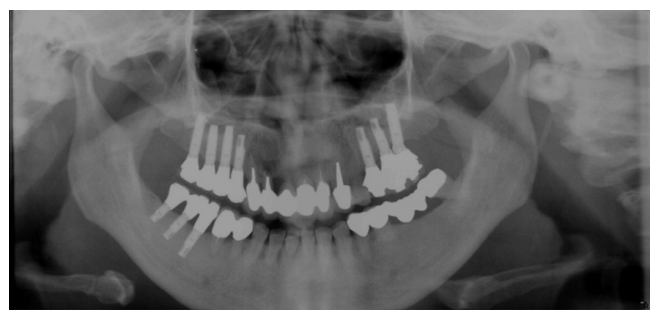

図 7 Panoramic radiograph after treatment 治療終了時のパノラマ写真

$り^{1)}$, 経過観察が重要になる.

本症例では, 上部構造物装着後 6 カ月ごとのメイン テナンスを行っているが，3 年経過後のインプラント部 の骨吸収や炎症は見受けられない. 残存歯の状態も安定 している.

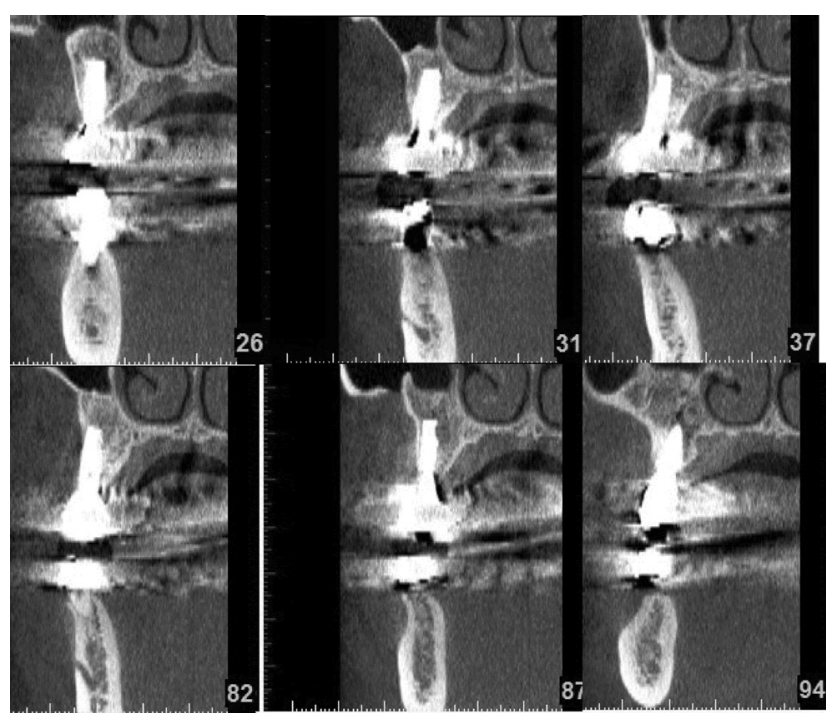

図 8 Panoramic radiograph at 3 years after treatment 装着 3 年後のパノラマ写真

術前， 臼歯部欠損により十分な咀嚼ができなかった患 者が，インプラント補綴による臼歯部咬合関係の修復を 行ったことにより, 咀嚼機能の回復だけでなく, 残存歯 の保護にも役立っていることが推測される。

\section{V. 結 論}

今回，上顎画側遊離端欠損の補綴治療において，上顎 洞底挙上術後のインプラント治療により咬合再構成を行 ったところ, 咀嚼機能の顕著な回復と患者の強い満足が 得られた。

よって，当該部の歯槽骨骨量が不足している場合にお いて，骨移植を伴ったインプラント治療が欠損補綴治療 としてきわめて有効な治療法であると考えられる.

今後も本症例が長期的に機能するように，定期的な経 過観察を続けていく予定である.

\section{文献}

1) Stephan SW, Stuart JF. Effect of maxillary sinus augmentation on the survival of endosseous dental implants. Ann Periodontol 2003; 8: 328-343.

著者連絡先 : 冨山 雅史

干 111-0034 東京都台東区雷門 2-11-8

TEL: 03-3844-4180

FAX: 03-3844-031 1

E-mail: taitou@taitou.net 